\title{
Prevotella paludivivens sp. nov., a novel strictly anaerobic, Gram-negative, hemicellulose- decomposing bacterium isolated from plant residue and rice roots in irrigated rice-field soil
}

\author{
Atsuko Ueki, Hiroshi Akasaka,† Atsuya Satoh,‡ Daisuke Suzuki \\ and Katsuji Ueki \\ Faculty of Agriculture, Yamagata University, Wakaba-machi 1-23, Tsuruoka 997-8555, Japan
}

Correspondence

Atsuko Ueki

uatsuko@tds1.tr.yamagata-u.ac.jp
Two strictly anaerobic bacterial strains, $K B 7^{\top}$ and $\mathrm{A} 42$, were isolated from rice plant residue and living rice roots, respectively, from irrigated rice-field soil in Japan. These two strains were closely related to each other with $16 \mathrm{~S}$ rRNA gene sequence similarity of $99.8 \%$. Both strains showed almost the same physiological properties. Cells were Gram-negative, non-motile, non-sporeforming rods. Growth was remarkably stimulated by the addition of haemin to the medium. The strains utilized various saccharides including xylan, xylose, pectin and carboxymethylcellulose and produced acetate and succinate with small amounts of formate and malate. The strains grew at $10-40{ }^{\circ} \mathrm{C}$; optimum growth was observed at $30{ }^{\circ} \mathrm{C}$ and $\mathrm{pH} 5.7-6.7$. Oxidase, catalase and nitrate-reducing activities were not detected. Aesculin was hydrolysed. The major cellular fatty acids were anteiso- $\mathrm{C}_{15: 0}$, iso- $\mathrm{C}_{15: 0}, \mathrm{C}_{15: 0}$ and iso- $\mathrm{C}_{17: 0} 3-\mathrm{OH}$. Menaquinones $\mathrm{MK}-11$ and MK-11 $\left(\mathrm{H}_{2}\right)$ were the major respiratory quinones and the genomic DNA $\mathrm{G}+\mathrm{C}$ content was $39.2 \mathrm{~mol} \%$. Phylogenetic analysis based on 16S rRNA gene sequences placed both strains in the phylum Bacteroidetes. 16S rRNA gene sequence analysis showed that the most related species to both strains was Prevotella oulorum (92.8-92.9\% similarity). Prevotella veroralis and Prevotella melaninogenica were the next most closely related known species with sequence similarities of $91.9-92.4 \%$. Based on differences in the phylogenetic, ecological, physiological and chemotaxonomic characteristics between the two isolates and related species, it is proposed that strains $\mathrm{KB} 7^{\top}$ and $\mathrm{A} 42$ represent a novel species, Prevotella paludivivens sp. nov. This is the first described Prevotella species derived from a natural habitat; all other Prevotella species are from mammalian sources. The type strain of Prevotella paludivivens is $\mathrm{KB}^{\top}$ (=JCM $13650^{\top}=$ DSM $17968^{\top}$ ).
In Japan, rice is widely cultivated as the principal food product in irrigated fields, the soil of which develops a highly reduced condition during the flooding period (Takai, 1970; Wassmann et al., 2000). Diverse fermentative bacterial groups play a key role in decomposition of organic matter, including plant residue such as rice straw, stubble and roots ploughed into the anoxic rice-field soil, thus producing methanogenic substrates such as acetate,

tPresent address: Creative Research Initiative 'Sousei' (CRIS), Hokkaido University, Kita 21, Nishi 10, Kita-ku, Sapporo 001-0021, Japan.

$\ddagger$ Present address: Graduate School of Agriculture, Hokkaido University, Kita 9, Nishi 9, Kita-ku, Sapporo 060-8589, Japan.

Abbreviations: CFA, whole-cell fatty acid; CMC, carboxymethylcellulose.

The GenBank/EMBL/DDBJ accession numbers for the 16S rRNA gene sequences of strains $\mathrm{KB}^{\top}$ and $\mathrm{A} 42$ are $\mathrm{AB} 078827$ and $\mathrm{AB081578}$, respectively. formate and $\mathrm{H}_{2}$. Living plant roots also provide growth substrates for microbes either by secreting organic matter such as saccharides, amino acids and organic acids or from cellular material peeling off the root epidermis and cortex (Kaku et al., 2000). Methane produced from decomposition of these substrates is emitted to the atmosphere as one of the major greenhouse gases (Takai, 1970; Seiler et al., 1984; Boone, 2000; Khalil, 2000; Wassmann et al., 2000).

Various fermentative anaerobes from samples of rice plant residue and living rice roots from irrigated rice-field soil have been isolated during the course of our investigations from microbes in anoxic rice-field soil (Satoh et al., 2002; Akasaka et al., 2003a, 2004). Of the isolates from rice plant residue, three novel propionate-producing species in the phyla Actinobacteria and Bacteroidetes have been described recently (Akasaka et al., 2003b; Ueki et al., 2006a, b). In this study, two other strains that are phylogenetically distant 
from any related recognized species have been isolated from rice plant residue and living rice roots and characterized. The isolates were strictly anaerobic, xylanolytic bacteria consisting of Gram-negative, non-motile rodlike cells. Although all recognized species in the genus Prevotella have been isolated from mammalian sources such as human oral, urogenital or other clinical sources and the rumen, it is proposed that the two strains isolated here $\left(\mathrm{KB}^{\mathrm{T}}\right.$ and $\left.\mathrm{A} 42\right)$ should be accommodated in the genus Prevotella as a novel species based on the comprehensive characterization carried out.

Strain $\mathrm{KB}^{\mathrm{T}}\left(=\mathrm{JCM} 13650^{\mathrm{T}}=\mathrm{DSM} 17968^{\mathrm{T}}\right)$ was isolated from a plant residue sample (rice stubble and roots) collected from irrigated rice-field soil in the Shonai Branch of the Yamagata Agricultural Experimental Station (Tsuruoka, Yamagata, Japan) during the flooding period of the field in June 1994 (Akasaka et al., 2003a). Strain A42 $(=$ JCM $13651=$ DSM 17969) was isolated from roots of living rice plants in the same field in August 1993 during the period of intermittent irrigation (Satoh et al., 2002). Cultivation practices for rice plants and other field conditions have been described previously (Ueki et al., 2000). Samples homogenized by a Waring blender (10000 r.p.m., 10 min.) under $\mathrm{N}_{2}$ gas were used for isolation (Satoh et al., 2002; Akasaka et al., 2003a, 2004). Strains were isolated by the anaerobic roll tube method for enumeration of anaerobic fermentative bacteria using the colony-counting method (Hungate, 1966; Holdeman et al., 1977).

The strains were cultivated anaerobically at $30{ }^{\circ} \mathrm{C}$ unless otherwise stated by using peptone-yeast extract (PY) medium as basal medium with $\mathrm{O}_{2}$-free $95 \% \mathrm{~N}_{2} / 5 \% \mathrm{CO}_{2}$ mixed gas in the headspace as described by Akasaka et al. (2003a, b). PY medium supplemented with $\left(1^{-1}\right) 0.25 \mathrm{~g}$ each of glucose, cellobiose, maltose and soluble starch plus $15 \mathrm{~g}$ agar (Difco) was designated PY4S agar and used for isolation and maintenance of the strain in agar slants. PY liquid medium supplemented with haemin (at a final concentration of $5 \mathrm{mg} \mathrm{l}^{-1}$ ) (Holdeman et al., 1977) (PYH medium) and the B-vitamin mixture $\left(10 \mathrm{ml} \mathrm{l}^{-1}\right.$ ) (PYHV medium) as well as $10 \mathrm{~g}$ glucose $1^{-1}$ (PYHVG medium) were used for cultivation of the strains for various physiological tests and chemotaxonomic analyses of the cells unless otherwise stated (Ueki et al., 2006b). The composition of the B-vitamin mixture used was $\left(100 \mathrm{ml}^{-1}\right) 0.1 \mathrm{mg}$ biotin, $0.1 \mathrm{mg}$ cyanocobalamin (vitamin $B_{12}$ ), $0.3 \mathrm{mg}$ p-aminobenzoic acid, $0.5 \mathrm{mg}$ folic acid, $0.5 \mathrm{mg}$ thiamine hydrochloride, $0.5 \mathrm{mg}$ riboflavin and $1.5 \mathrm{mg}$ pyridoxine hydrochloride (Akasaka et al., 2004). Growth in liquid medium was monitored by changes in $\mathrm{OD}_{660}$.

Growth of the strains under aerobic conditions was examined by plate culture on nutrient agar (Nissui Pharmacy) and PY4S agar modified to exclude $\mathrm{Na}_{2} \mathrm{CO}_{3}$, cysteine- $\mathrm{HCl}-\mathrm{H}_{2} \mathrm{O}$ and sodium resazurin in the PY basal medium. Spore formation was assessed by observation of cells after Gram-staining and by growth of cells exposed to $80{ }^{\circ} \mathrm{C}$ for $10 \mathrm{~min}$. Oxidase, catalase and nitrate-reducing activities were determined according to methods described by Satoh et al. (2002) and Akasaka et al. (2003a, b). Utilization of carbon sources was tested in PYHV liquid medium with each substrate added at $10 \mathrm{~g} \mathrm{l}^{-1}$ (for sugars and sugar alcohols) or $30 \mathrm{mM}$ (organic acids). Bile sensitivity was determined by the addition of bile salts (0.1-0.5\%, w/v; Oxoid) to PYHVG and PYG media (Lawson et al., 2002). Fermentation products were analysed by GC or HPLC as described previously (Ueki et al., 1986; Akasaka et al., 2003a). Other characterizations were performed according to methods described by Holdeman et al. (1977) and Ueki et al. (2006a, b).

Whole-cell fatty acids (CFAs) were converted to methyl esters according to the method of Miller (1982). Methyl esters of CFAs were analysed by GC [HP6890 (Hewlett Packard) or G-3000 (Hitachi)] equipped with an HP Ultra2 column. CFAs were identified by equivalent chain-length (Miyagawa et al., 1979; Ueki \& Suto, 1979) according to the protocol of TechnoSuruga (Shimidu, Japan), based on the MIDI Microbial Identification System (Microbial ID; Moore et al., 1994). The TSBA40 microbial identification system was also used to confirm identification. Isoprenoid quinones were extracted as described by Komagata \& Suzuki (1987) and analysed by MS (JMS-SX102A; JEOL). Genomic DNA was extracted according to the method of Kamagata \& Mikami (1991). Extracted DNA was digested with P1 nuclease by using a GC kit (Yamasa shoyu) and its $\mathrm{G}+\mathrm{C}$ content was measured by HPLC (Hitachi L-7400) equipped with a $\mu$ Bondapack C18 column $(3.9 \times 300 \mathrm{~mm}$; Waters).

DNA extraction and PCR amplification were performed according to the method described by Akasaka et al. (2003a). The 16S rRNA gene was PCR amplified using the $27 \mathrm{f}$ and $1492 \mathrm{r}$ primer set and sequenced by using a ThermoSequenase Primer Cycle Sequencing kit (Amersham Biosciences) and a DNA sequencer (4000L; LI-COR). Multiple alignments of the sequence with reference sequences in GenBank were performed with the program BLAST (Altschul et al., 1997). A phylogenetic tree was constructed with the neighbour-joining method (Saitou \& Nei, 1987) by using the program CLUSTAL W (Thompson et al., 1994). All gaps and unidentified base positions in the alignments were excluded before sequence assembly.

Cellular and various physiological characteristics were determined for strains $\mathrm{KB}^{\mathrm{T}}$ and $\mathrm{A} 42$ and they showed almost the same phenotypic properties. Of the physiological characteristics of both strains shown below, detailed descriptions such as growth rates and amounts of products were based mainly on data from strain $\mathrm{KB}^{\mathrm{T}}$ as the representative strain.

Cells of both strains were Gram-negative rods, $0.7-0.8 \mu \mathrm{m}$ in width and 1.3-2.1 $\mu \mathrm{m}$ in length with some longer (4.0$12.0 \mu \mathrm{m}$ ) cells (Fig. 1). Cells were non-motile as observed 


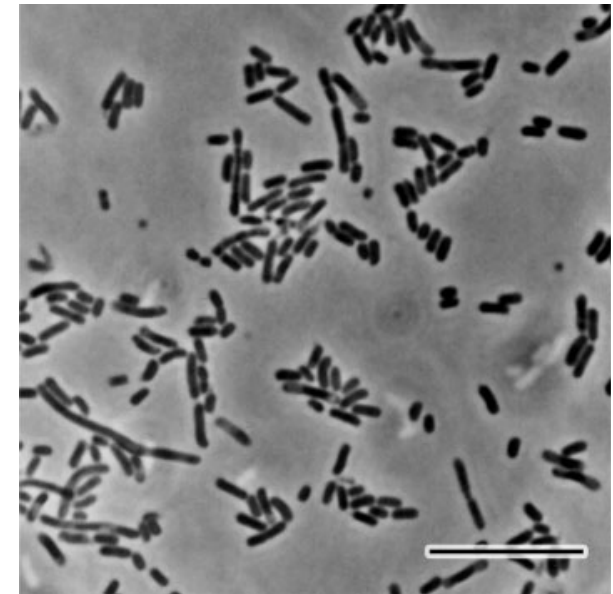

Fig. 1. Phase-contrast photomicrograph of cells of strain $K B 7^{\top}$ grown anaerobically on agar slants of PY4S. Bar, $10 \mu \mathrm{m}$.

by phase-contrast microscopy. Colonies on PY4S agar were translucent and thin with a smooth surface. Neither strain could grow in air on PY4S or nutrient agar. Spore formation was not observed and cells treated at $80{ }^{\circ} \mathrm{C}$ for 10 min did not grow. Catalase and oxidase activities were not detected.

The strains grew very slowly in PYG liquid medium without haemin at a growth rate $(\mu)$ of $0.092 \mathrm{~h}^{-1}$ at $30{ }^{\circ} \mathrm{C}$; the addition of haemin to the medium greatly enhanced growth $\left(\mu=0.40-0.45 \mathrm{~h}^{-1}\right)$. The addition of haemin did not significantly affect the morphology of the cells (Ueki et al., 2006b). Further addition of vitamin $\mathrm{K}$ to the medium did not seem to affect the growth rate. Although addition of the B-vitamin mixture did not stimulate growth, it seemed to bring about stable growth behaviour of the strains. Thus, physiological characteristics of the strains were usually determined in the presence of B-vitamin mixture plus haemin (PYHV medium). Cells for chemotaxonomic characterization were also cultivated in the presence of these growth factors (PYHVG medium).

Both strains utilized arabinose, xylose, fructose, galactose, glucose, mannose, rhamnose, cellobiose, lactose, maltose, sucrose, carboxymethylcellulose (CMC), soluble starch, xylan, pectin and salicin as growth substrates. Ribose, pyruvate and fumarate were utilized weakly. Acids were produced from all substrates utilized, but gas was not. The strains did not use sorbose, trehalose, melezitose, cellulose powder, filter paper, inulin, glycerol, inositol, mannitol, lactate, malate or succinate.

Fermentation products in PYG medium (without haemin and vitamins) were acetate $(2.6 \mathrm{mM})$, succinate $(4.1 \mathrm{mM})$ and malate $(5.9 \mathrm{mM})$, whereas in the presence of haemin and vitamins (PYHVG medium), both strains produced acetate $(9.2 \mathrm{mM})$ and succinate $(15.9 \mathrm{mM})$ as major acids with lower amounts of formate $(2.6 \mathrm{mM})$ and malate $(0.4 \mathrm{mM})$. Almost the same amounts of acetate and succinate were produced from the other substrates tested, including xylan and pectin. Acid production from CMC was rather weak (3.4 mM acetate and $6.1 \mathrm{mM}$ succinate). Products from fumarate were acetate $(3.9 \mathrm{mM})$, succinate $(6.6 \mathrm{mM})$, malate $(8.8 \mathrm{mM})$ and a trace amount of formate; products from pyruvate were formate $(3.9 \mathrm{mM})$, acetate $(8.9 \mathrm{mM})$, succinate $(4.1 \mathrm{mM})$ and a trace amount of malate. Aesculin was hydrolysed, but gelatin was not. The strains were negative for the production of urease, hydrogen sulfide and indole. They did not reduce nitrate and could not grow in the presence of $0.1 \%(\mathrm{w} / \mathrm{v})$ bile salts.

The strains grew at $\mathrm{pH}$ 4.7-7.6, with optimum growth at $\mathrm{pH}$ 5.7-6.7, a rather wide $\mathrm{pH}$ range for optimum growth. The final $\mathrm{pH}$ of the PYHVG medium was about $\mathrm{pH} 4.5$. The temperature range for growth was $10-40{ }^{\circ} \mathrm{C}$, with optimum growth at $30{ }^{\circ} \mathrm{C}$. The growth rate at $37^{\circ} \mathrm{C}$ $\left(\mu=0.35 \mathrm{~h}^{-1}\right)$ was rather high, but it dropped sharply to a much lower level at $40{ }^{\circ} \mathrm{C}\left(\mu=0.071 \mathrm{~h}^{-1}\right)$. The growth rate at $10{ }^{\circ} \mathrm{C}$ was $0.019 \mathrm{~h}^{-1}$. The $\mathrm{NaCl}$ concentration range for growth was $0-1.0 \%(\mathrm{w} / \mathrm{v})$.

The major CFAs of strain $\mathrm{KB}^{\mathrm{T}}$ were anteiso- $\mathrm{C}_{15: 0}$ $(27.3 \%)$, iso- $\mathrm{C}_{15: 0}(11.9 \%), \mathrm{C}_{15: 0}(10.1 \%)$, iso- $\mathrm{C}_{17: 0} 3$ $\mathrm{OH}(9.1 \%)$, iso- $\mathrm{C}_{14: 0}(7.9 \%)$ and $\mathrm{C}_{16: 0} 3-\mathrm{OH}(6.8 \%)$, with lower amounts of iso- $\mathrm{C}_{13: 0}(4.4 \%), \mathrm{C}_{14: 0}(3.9 \%)$, iso- $\mathrm{C}_{16: 0} 3-\mathrm{OH}(3.9 \%)$ and $\mathrm{C}_{16: 0}(3.3 \%)$. Unsaturated fatty acids were not detected. The predominant respiratory quinones of strain $\mathrm{KB}^{\mathrm{T}}$ were menaquinones MK-11 and MK-11 $\left(\mathrm{H}_{2}\right)$. The genomic DNA G $+\mathrm{C}$ content was $39.2 \mathrm{~mol} \%$. These chemotaxonomic analyses were not carried out for strain A42.

The similarity between the 16S rRNA gene sequences of strains $\mathrm{KB}^{\mathrm{T}}$ and $\mathrm{A} 42$ was $99.8 \%$ and both strains were assigned to the phylum Bacteroidetes (Garrity \& Holt, 2001). The closest relative to both strains in the GenBank database was Prevotella sp. HY-36-2 (AY581270) with sequence similarity of $98.7-99.0 \%$. Of species with validly described names, the species most closely related to both strains all belonged to the genus Prevotella, i.e. Prevotella oulorum ATCC $43324^{\mathrm{T}}$ (Shah et al., 1985; 92.8-92.9\% similarity), Prevotella veroralis ATCC $33779^{\mathrm{T}}$ (Watabe et al., 1983; 92.0-92.4\%) and Prevotella melaninogenica ATCC $25845^{\mathrm{T}}$ (Holdeman et al., 1984; 91.9-92.0\%). The next most closely related species were Prevotella corporis and Prevotella bryantii (Holdeman et al., 1984; Avgustin et al., 1997; 91.1-92.0\% similarity). Strains $\mathrm{KB}^{\mathrm{T}}$ and A42 formed a separate branch from related Prevotella species in the phylogenetic tree composed of all recognized Prevotella species (Fig. 2).

The genus Prevotella consists of species almost exclusively isolated from human oral, urogenital or other clinical sources (Shah \& Collins, 1989, 1990; Paster et al., 1994) including recently described species (Sakamoto et al., 2004, 2005a, b; Berger et al., 2005; Downes et al., 2005, 2006), with the exception of species isolated from the rumen (Avgustin et al., 1997). Thus, the habitats of strains $\mathrm{KB}^{\mathrm{T}}$ 


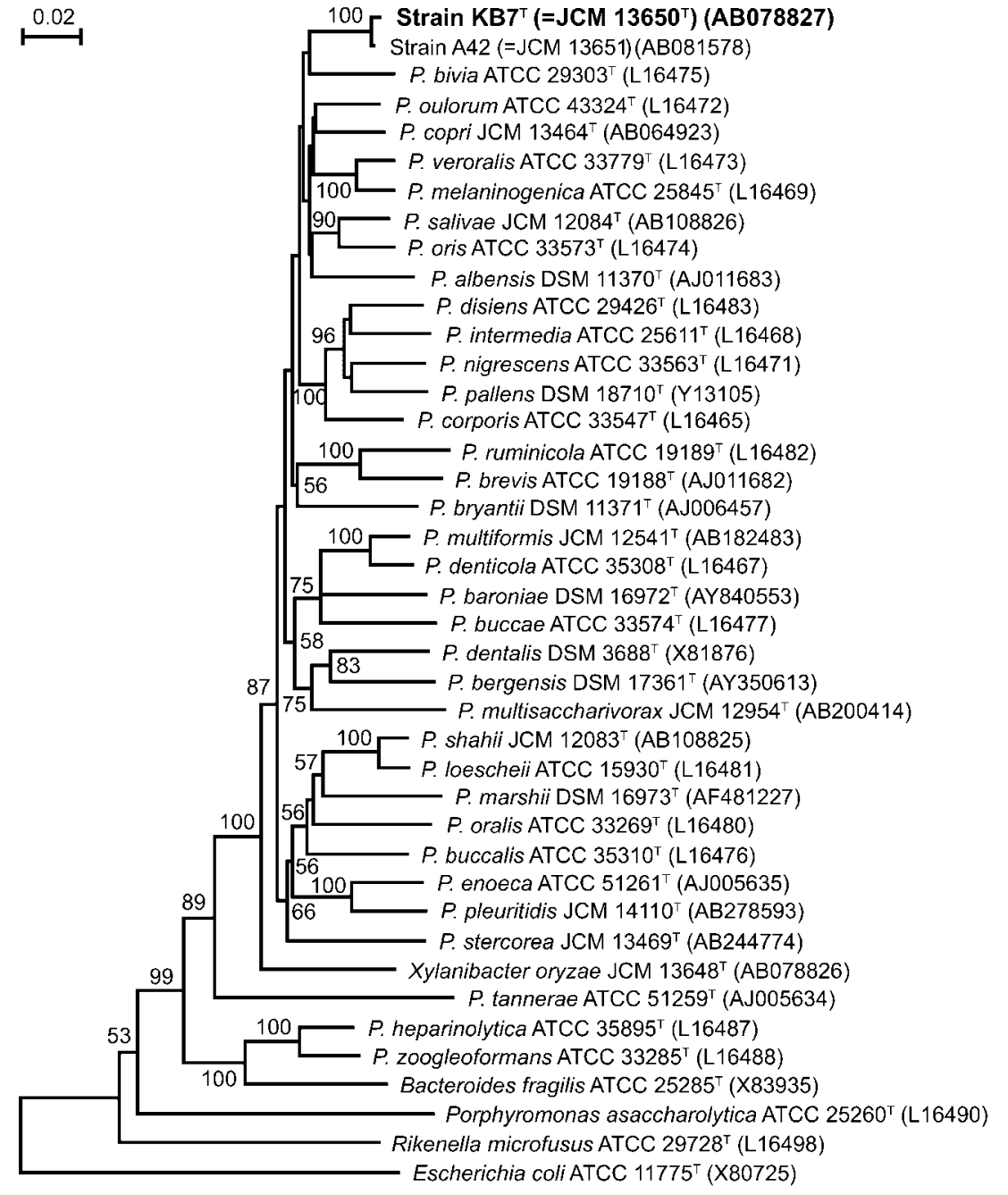

Fig. 2. Neighbour-joining tree showing the phylogenetic relationship of strains $\mathrm{KB}^{\top}$ and A42, all species in the genus Prevotella and the type species of related genera (Bacteroides, Porphyromonas, Rikenella and Xylanibacter) based on 16S rRNA gene sequences. The phylogenetic tree was constructed by using $1111 \mathrm{nt}$ of the 16S rRNA gene sequence. Bootstrap values (expressed as percentages of 1000 replications) above $50 \%$ are shown at branch nodes. Bar, $2 \%$ estimated difference in nucleotide sequence position. The sequence of Escherichia coli ATCC $11775^{\top}$, which belongs to the class Gammaproteobacteria (Garrity \& Holt, 2001), was used as the outgroup. and A42 are extremely different, i.e. rice plant residue in flooded rice-field soil and living rice roots, from those of currently known Prevotella species. The optimum growth temperature of the strains is $30{ }^{\circ} \mathrm{C}$ and they grow only weakly at $40{ }^{\circ} \mathrm{C}$; thus, the temperature of mammals at around $37{ }^{\circ} \mathrm{C}$ is near the upper limit for growth of both strains.

Many species in the genus Prevotella have a requirement for haemin for growth; the closest relatives of strains $\mathrm{KB}^{\mathrm{T}}$ and A42 also require haemin for growth or they are usually cultivated in the presence of haemin (Holdeman et al., 1984; Shah et al., 1985). Growth of our strains was also strongly stimulated by the addition of haemin to the medium. Xylanibacter oryzae strain $\mathrm{KB}^{\mathrm{T}}$, isolated from plant residue in the same rice field as strain $K B 7^{\mathrm{T}}$, also requires haemin for growth (Ueki et al., 2006b).

Some characteristics of strain $\mathrm{KB}^{\mathrm{T}}$, as representative strain, were compared with those of the three most closely related known species ( $P$. oulorum, $P$. veroralis and $P$. melaninogenica) (Table 1). Substrates that can be utilized by these related species are relatively limited; these species are not able to utilize pentoses (arabinose and xylose), rhamnose or salicin, which are utilized by strains $K B 7^{\mathrm{T}}$ and A42. Furthermore, the two isolates utilized polysaccharides such as xylan, pectin and CMC, whereas the related species did not utilize these polymers except for xylan-utilizing $P$. veroralis. In addition, $\mathrm{KB}^{\mathrm{T}}, \mathrm{A} 42$ and $P$. veroralis utilized cellobiose, whereas the other two species did not.

Strains $\mathrm{KB}^{\mathrm{T}}$ and $\mathrm{A} 42$ produced acetate and succinate as major acids from glucose and other closely related species also produce these acids from carbohydrates. Thus, both strains have a common feature with respect to fermentation products with the related species (Holdeman et al., 1984; Shah et al., 1985).

The $\mathrm{G}+\mathrm{C}$ content of genomic DNA of strain $\mathrm{KB}^{\mathrm{T}}$ (39.2 $\mathrm{mol} \%$ ) is close to those of $P$. veroralis $(42.1 \mathrm{~mol} \%)$ and $P$. melaninogenica $(36-40 \mathrm{~mol} \%)$ and slightly lower than that of P. oulorum (45-46 mol\%) (Watabe et al., 1983; Holdeman et al., 1984; Shah et al., 1985). Many Prevotella species have menaquinone MK-11 as one of the predominant menaquinones (Shah \& Collins, 1980) and strain $\mathrm{KB}^{\mathrm{T}}$ possesses menaquinones MK-11 and 
Table 1. Characteristics that differentiate strain $\mathrm{KB} 7^{\top}$ and other related Prevotella species

Strains: 1, Strain KB7 ${ }^{\mathrm{T}}$; 2, P. oulorum NCTC $11871^{\mathrm{T}}$ (Shah et al., 1985); 3, P. veroralis ATCC 33779 ${ }^{\mathrm{T}}$ (Watabe et al., 1983; Shah et al., 1985); 4, P. melaninogenica ATCC $25845^{\mathrm{T}}$ (Holdeman et al., 1984; Sakamoto et al., 2005a). +, Positive; -, negative; ND, no data available. F, formate (minor product); A, acetate; $\mathrm{s}$, succinate.

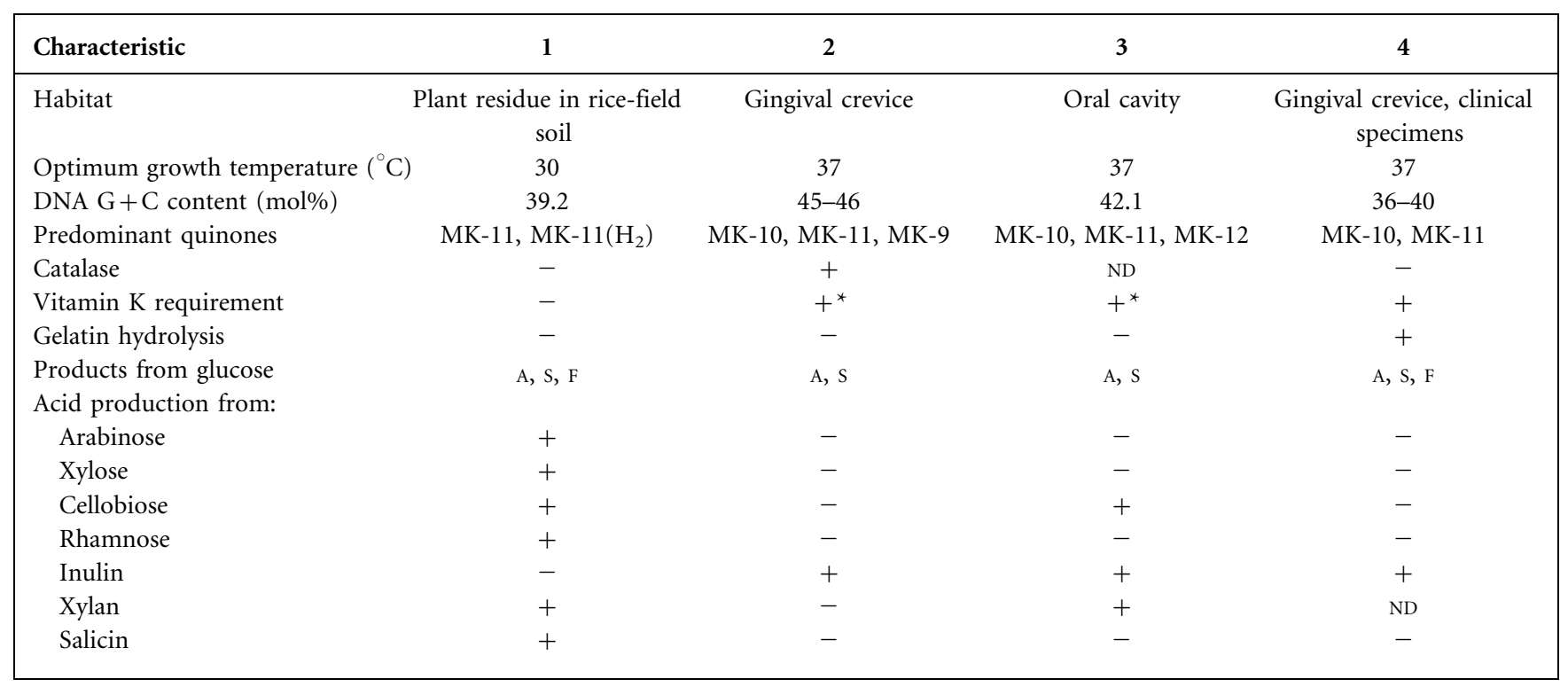

${ }^{*}$ Vitamin $\mathrm{K}$ is usually added to the medium.

MK-11 $\left(\mathrm{H}_{2}\right)$. Although the presence of hydrogenated menaquinone, MK-11 $\left(\mathrm{H}_{2}\right)$, is rather rare in Prevotella species (Shah \& Collins, 1980; Sakamoto et al., 2005a), strain $\mathrm{KB}^{\mathrm{T}}$ and related Prevotella species do share a common menaquinone.

It has been reported that the major CFAs in species of the two genera Bacteroides and Prevotella are anteiso- $\mathrm{C}_{15: 0}$, iso- $\mathrm{C}_{15: 0}$, iso- $\mathrm{C}_{17: 0} 3-\mathrm{OH}$ and $\mathrm{C}_{16: 0}$ (Miyagawa et al., 1979; Moore et al., 1994). Although $C_{16: 0}$ is only a minor component of CFAs of strain $\mathrm{KB}^{\mathrm{T}}$, the overall pattern of the CFA composition with anteiso- $\mathrm{C}_{15: 0}$ and iso- $\mathrm{C}_{17: 0} 3-$ $\mathrm{OH}$ as major components seems to have a common profile to those reported for Bacteroides and Prevotella species. However, the CFA composition of strain $\mathrm{KB}^{\mathrm{T}}$ is actually rather different from that of $P$. oulorum in the levels of some CFAs such as $\mathrm{C}_{15: 0}$ and iso- $\mathrm{C}_{17: 0}$ (Shah et al., 1985). Furthermore, although $P$. veroralis and $P$. melaninogenica have an unsaturated fatty acid $\left(\mathrm{C}_{18: 1}\right)$ as one of the most dominant CFAs (17.2 and $17.9 \%$, respectively) (Sakamoto et al., 2004), strain $\mathrm{KB}^{\mathrm{T}}$ does not contain unsaturated fatty acids (Table 2).

Strain $\mathrm{KB}^{\mathrm{T}}$ was isolated from rice plant residue (plant stubble and roots) together with three other strains (strains KB1, KB9 and KB12) (Akasaka et al., 2003a) and strain A42 was isolated from living rice roots as one of the predominant culturable anaerobic bacteria (Satoh et al., 2002). Hemicellulose together with cellulose and lignin make up the major polymeric constituents of plant cell walls. Hemicellulose is a heteropolysaccharide composed of various sugars such as xylose, arabinose, glucose, galactose and mannose. Xylan is composed of xylose and constitutes the major component of hemicellulose (Collins et al., 2005). Pectin also occurs in the primary cell walls and intercellular regions of plants. It is known that pectin, which is a complex polysaccharide composed mainly of galacturonic acid, usually contains rhamnose residues as important components. Strains $\mathrm{KB}^{\mathrm{T}}$ and $\mathrm{A} 42$ both utilized these plant polymers (xylan, pectin and CMC) as well as the major components of the polymeric constituents. Both strains also utilized cellobiose, which is generated by hydrolysis of cellulose. Thus, it was strongly suggested that the bacterial group related to strains $\mathrm{KB}^{\mathrm{T}}$ and A42 should take an important part in decomposition of the plant cell wall, especially hemicellulose and pectin, including intermediate substrates derived from the decomposition of plant cell walls. The isolation of strain A42 from living rice roots indicates that the bacterial group colonizes rice roots before harvesting of rice and plays an important role in the decay of rice roots in rice-field soil.

Strains $\mathrm{KB}^{\mathrm{T}}$ and $\mathrm{A} 42$ have some features in common with those of related Prevotella species as shown above, although these related species are all isolated from human clinical specimens and all known species in the genus Prevotella are derived from mammalian sources (Fig. 2). In addition to low $16 \mathrm{~S}$ rRNA gene sequence similarities, the obvious ecological difference suggests that strains $\mathrm{KB}^{\mathrm{T}}$ and $\mathrm{A} 42$ should represent a novel species in the genus Prevotella, 
Table 2. Cellular fatty acid composition (\%) of strain $\mathrm{KB}^{\top}$ and other related Prevotella species

Strains: $1, \mathrm{~KB}^{\mathrm{T}}$; 2, P. oulorum NCTC $11871^{\mathrm{T}}$ (Shah et al., 1985); 3, P. veroralis JCM $6290^{\mathrm{T}}$ (Sakamoto et al., 2004); 4. P. melaninogenica JCM $6325^{\mathrm{T}}$ (Sakamoto et al., 2004). TR, Trace; -, not detected.

\begin{tabular}{|c|c|c|c|c|}
\hline Fatty acid & 1 & 2 & 3 & 4 \\
\hline \multicolumn{5}{|l|}{ Saturated straight-chain } \\
\hline $\mathrm{C}_{14: 0}$ & 3.9 & 0.9 & $\mathrm{TR}$ & 1.2 \\
\hline $\mathrm{C}_{15: 0}$ & 10.1 & 0.8 & - & $\mathrm{TR}$ \\
\hline $\mathrm{C}_{16: 0}$ & 3.3 & 6.3 & 5.5 & 9.1 \\
\hline $\mathrm{C}_{17: 0}$ & - & 0.2 & - & - \\
\hline $\mathrm{C}_{18: 0}$ & 0.3 & 4.5 & 0.9 & 1.2 \\
\hline \multicolumn{5}{|c|}{ Unsaturated straight-chain } \\
\hline $\mathrm{C}_{16: 1}$ & - & TR & 1.2 & 2.0 \\
\hline $\mathrm{C}_{18: 2}$ & - & - & 1.4 & 2.3 \\
\hline $\mathrm{C}_{18: 1}$ & - & 0.8 & 17.2 & 17.9 \\
\hline \multicolumn{5}{|l|}{ Hydroxy acids } \\
\hline iso- $\mathrm{C}_{15: 0} 3-\mathrm{OH}$ & - & 0.2 & 0.6 & - \\
\hline $\mathrm{C}_{15: 0} 3-\mathrm{OH}$ & - & 0.1 & - & - \\
\hline iso- $\mathrm{C}_{16: 0} 3-\mathrm{OH}$ & 3.9 & 0.2 & 1.3 & 1.3 \\
\hline $\mathrm{C}_{16: 0} 3-\mathrm{OH}$ & 6.8 & 2.5 & 2.8 & 4.8 \\
\hline iso- $\mathrm{C}_{17: 0} 3-\mathrm{OH}$ & 9.1 & 6.8 & 13.5 & 9.6 \\
\hline anteiso- $\mathrm{C}_{17: 0} 3-\mathrm{OH}$ & 2.1 & - & 1.5 & 1.7 \\
\hline $\mathrm{C}_{17: 0} 3-\mathrm{OH}$ & 0.6 & 0.2 & $\mathrm{TR}$ & - \\
\hline \multicolumn{5}{|c|}{ Saturated branched-chain } \\
\hline iso- $\mathrm{C}_{13: 0}$ & 4.4 & - & $\mathrm{TR}$ & - \\
\hline anteiso- $\mathrm{C}_{13: 0}$ & 1.9 & 0.8 & - & - \\
\hline iso- $\mathrm{C}_{14: 0}$ & 7.9 & 1.4 & 3.6 & 2.8 \\
\hline iso- $\mathrm{C}_{15: 0}$ & 11.9 & 15.5 & 6.7 & 8.2 \\
\hline anteiso- $\mathrm{C}_{15: 0}$ & 27.3 & 37.0 & 23.5 & 25.2 \\
\hline iso- $\mathrm{C}_{16: 0}$ & - & 3.4 & 3.3 & 1.9 \\
\hline iso- $\mathrm{C}_{17: 0}$ & 0.1 & 11.8 & 2.1 & 1.2 \\
\hline anteiso- $\mathrm{C}_{17: 0}$ & 0.2 & 6.3 & 3.4 & 2.1 \\
\hline
\end{tabular}

having a significantly different ecological function from those Prevotella species living in mammals.

On the basis of the above-mentioned comprehensive analyses of the phylogenetic, phenotypic and chemotaxonomic characteristics, as well as the ecological and functional properties, the novel species Prevotella paludivivens sp. nov. is proposed to accommodate strains $\mathrm{KB}^{\mathrm{T}}$ and A42.

\section{Description of Prevotella paludivivens sp. nov.}

Prevotella paludivivens (pa.lu.di.vi'vens. L. n. palus, -udis swamp, marsh; L. v. vivo to live; N.L. part. adj. paludivivens living in swamps).

Cells are Gram-negative, non-spore-forming, non-motile, short rods. Strictly anaerobic. Chemo-organotroph. Haemin significantly stimulates growth. $\mathrm{pH}$ optimum for growth is 5.7-6.7. Temperature range for growth is 10 $40{ }^{\circ} \mathrm{C}$, with optimum growth at $30{ }^{\circ} \mathrm{C}$. Growth at $37{ }^{\circ} \mathrm{C}$ is delayed compared with that at $30^{\circ} \mathrm{C}$. $\mathrm{NaCl}$ concentration range for growth is $0-1.0 \%(\mathrm{w} / \mathrm{v})$ in PYG medium. Oxidase, catalase and nitrate-reducing activities are not detected. Utilizes arabinose, ribose, xylose, fructose, galactose, glucose, mannose, rhamnose, cellobiose, lactose, maltose, sucrose, CMC, soluble starch, xylan, pectin and salicin as growth substrates and produces acetate and succinate as major fermentation end products. Gas is not produced. Pyruvate and fumarate are also utilized. Does not use sorbose, trehalose, melezitose, cellulose powder, filter paper, inulin, glycerol, inositol, mannitol, lactate, malate or succinate. Hydrolyses aesculin, but not gelatin. Urease-negative. Hydrogen sulfide and indole are not produced. Does not grow in the presence of bile salts. The major cellular fatty acids are anteiso- $\mathrm{C}_{15: 0}$, iso- $\mathrm{C}_{15: 0}, \mathrm{C}_{15: 0}$ and iso- $\mathrm{C}_{17: 0} 3-\mathrm{OH}$. Major respiratory quinones are MK11 and $\mathrm{MK}-11\left(\mathrm{H}_{2}\right)$.

The type strain is $\mathrm{KB}^{\mathrm{T}}\left(=\mathrm{JCM} 13650^{\mathrm{T}}=\mathrm{DSM} 17968^{\mathrm{T}}\right)$, isolated from rice plant residue in flooded rice-field soil; the genomic DNA G $+\mathrm{C}$ content of strain $\mathrm{KB7}^{\mathrm{T}}$ is $39.2 \mathrm{~mol} \%$. Strain A42 (=JCM 13651 =DSM 17969) is a reference strain derived from rice roots of living rice plants.

\section{Acknowledgements}

This work was partly supported by a Grant-in-Aid from the Institute for Fermentation, Osaka. We are grateful to Yoshimi Ohtaki for her technical assistance on physiological examinations of the strains.

We thank Dr. K. Takahashi for his technical advice on the analysis of isoprenoid quinones.

\section{References}

Akasaka, H., Izawa, T., Ueki, K. \& Ueki, A. (2003a). Phylogeny of numerically abundant culturable anaerobic bacteria associated with degradation of rice plant residue in Japanese paddy field soil. FEMS Microbiol Ecol 43, 149-161.

Akasaka, H., Ueki, A., Hanada, S., Kamagata, Y. \& Ueki, K. (2003b). Propionicimonas paludicola gen. nov., sp. nov., a novel facultatively anaerobic, Gram-positive, propionate-producing bacterium isolated from plant residue in irrigated rice-field soil. Int J Syst Evol Microbiol 53, 1991-1998.

Akasaka, H., Ueki, K. \& Ueki, A. (2004). Effects of plant residue extract and cobalamin on growth and propionate production of Propionicimonas paludicola isolated from plant residue in irrigated rice field soil. Microbes Environ 19, 112-119.

Altschul, S. F., Madden, T. L., Schäffer, A. A., Zhang, J., Zhang, Z., Miller, W. \& Lipman, D. J. (1997). Gapped BLAST and PSI-BLAST: a new generation of protein database search programs. Nucleic Acids Res 25, 3389-3402.

Avgustin, G., Wallace, R. J. \& Flint, H. (1997). Phenotypic diversity among ruminal isolates of Prevotella ruminicola: proposal of Prevotella brevis sp. nov., Prevotella bryantii sp. nov., and Prevotella albensis sp. nov. and redefinition of Prevotella ruminicola. Int J Syst Bacteriol 47, 284-288.

Berger, P., Adékambi, T., Mallet, M.-N. \& Drancourt, M. (2005). Prevotella massiliensis sp. nov. isolated from human blood. Res Microbiol 156, 967-973.

Boone, R. D. (2000). Biological formation and consumption of methane. In Atmospheric Methane, pp. 42-62. Edited by M. A. K. Khalil. Berlin: Springer. 
Collins, T., Gerday, C. \& Feller, G. (2005). Xylanases, xylanase families and extremophilic xylanases. FEMS Microbiol Rev 29, 3-23.

Downes, J., Sutcliffe, I., Tanner, A. C. R. \& Wade, W. G. (2005). Prevotella marshii sp. nov. and Prevotella baroniae sp. nov., isolated from the human oral cavity. Int J Syst Evol Microbiol 55, 1551-1555.

Downes, J., Sutcliffe, I. C., Hofstad, T. \& Wade, W. G. (2006). Prevotella bergensis sp. nov., isolated from human infections. Int J Syst Evol Microbiol 56, 609-612.

Garrity, G. M. \& Holt, J. G. (2001). The road map to the Manual. In Bergey's Manual of Systematic Bacteriology, 2nd edn, vol. 1, pp. 119166. Edited by D. R. Boone, R. W. Castenholz \& G. M. Garrity. New York: Springer.

Holdeman, L. V., Cato, E. P. \& Moore, W. E. C. (1977). Anaerobe Laboratory Manual, 4th edn. Blacksburg, VA: Virginia Polytechnic Institute and State University.

Holdeman, L. V., Kelly, R. W. \& Moore, W. E. C. (1984). Genus I. Bacteroides Castellani and Chalmers 1919, 959 ${ }^{\mathrm{AL}}$. In Bergey's Manual of Systematic Bacteriology, vol. 1, pp. 604-631. Edited by N. R. Krieg \& J. G. Holt. Baltimore: Williams \& Wilkins.

Hungate, R. E. (1966). The Rumen and Its Microbes. New York: Academic Press.

Kaku, N., Ueki, A., Fujii, H. \& Ueki, K. (2000). Methanogenic activities on rice roots and plant residue and their contribution to methanogenesis in wetland rice field soil. Soil Biol Biochem 32, 2001-2010.

Kamagata, Y. \& Mikami, E. (1991). Isolation and characterization of a novel thermophilic Methanosaeta strain. Int J Syst Bacteriol 41, 191-196.

Khalil, M. A. K. (2000). Atmospheric Methane. Berlin: Springer.

Komagata, K. \& Suzuki, K. (1987). Lipid and cell-wall analysis in bacterial systematics. Methods Microbiol 19, 161-207.

Lawson, P. A., Falsen, E., Inganas, E., Weyant, R. S. \& Collins, M. D. (2002). Dysgonomonas mossi sp. nov., from human sources. Syst Appl Microbiol 25, 194-197.

Miller, L. T. (1982). Single derivatization method for routine analysis of bacterial whole-cell fatty acid methyl esters, including hydroxyl acids. J Clin Microbiol 16, 584-586.

Miyagawa, E., Azuma, R. \& Suto, E. (1979). Cellular fatty acid composition in Gram-negative obligately anaerobic rods. J Gen Appl Microbiol 25, 41-51.

Moore, L. V. H., Bourne, D. M. \& Moore, W. E. C. (1994). Comparative distribution and taxonomic value of cellular fatty acids in thirtythree genera of anaerobic Gram-negative bacilli. Int J Syst Bacteriol 44, 338-347.

Paster, B. J., Dewhirst, F. E., Olsen, I. \& Fraser, G. J. (1994). Phylogeny of Bacteroides, Prevotella, and Porphyromonas spp. and related species. J Bacteriol 176, 725-732.

Saitou, N. \& Nei, M. (1987). The neighbor-joining method: a new method for reconstructing phylogenetic trees. Mol Biol Evol 4, 406-425.

Sakamoto, M., Suzuki, M., Huang, Y., Umeda, M., Ishikawa, I. \& Benno, Y. (2004). Prevotella shahii sp. nov. and Prevotella salivae sp. nov., isolated from the human oral cavity. Int J Syst Evol Microbiol 54, 877-883.
Sakamoto, M., Huang, Y., Umeda, M., Ishikawa, I. \& Benno, Y. (2005a). Prevotella multiformis sp. nov., isolated from human subgingival plaque. Int J Syst Evol Microbiol 55, 815-819.

Sakamoto, M., Umeda, M., Ishikawa, I. \& Benno, Y. (2005b). Prevotella multisaccharivorax sp. nov., isolated from human subgingival plaque. Int J Syst Evol Microbiol 55, 1839-1843.

Satoh, A., Watanabe, M., Ueki, A. \& Ueki, K. (2002). Physiological properties and phylogenetic affiliations of anaerobic bacteria isolated from roots of rice plants cultivated on a paddy field. Anaerobe 8, 233-246.

Seiler, W., Holzapfel-Pschorn, A., Conrad, R. \& Scharffe, D. (1984). Methane emission from rice paddies. J Atmos Chem 1, 241-268.

Shah, H. N. \& Collins, M. D. (1980). Fatty acid and isoprenoid quinone composition in the classification of Bacteroides melaninogenicus and related taxa. J Appl Bacteriol 48, 75-87.

Shah, H. N. \& Collins, M. D. (1989). Proposal to restrict the genus Bacteroides (Castellani and Chalmers) to Bacteroides fragilis and closely related species. Int J Syst Bacteriol 39, 85-87.

Shah, H. N. \& Collins, M. D. (1990). Prevotella, a new genus to include Bacteroides melaninogenicus and related species formerly classified in the genus Bacteroides. Int J Syst Bacteriol 40, 205-208.

Shah, H. N., Collins, M. D., Watabe, J. \& Mitsuoka, T. (1985). Bacteroides oulorum sp. nov., a non-pigmented saccharolytic species from the oral cavity. Int J Syst Bacteriol 35, 193-197.

Takai, Y. (1970). The mechanism of methane fermentation in flooded paddy soil. Soil Sci Plant Nutr 6, 238-244.

Thompson, J. D., Higgins, D. G. \& Gibson, T. J. (1994). CLUSTAL W: improving the sensitivity of progressive multiple sequence alignment through sequence weighting, position-specific gap penalties and weight matrix choice. Nucleic Acids Res 22, 4673-4680.

Ueki, A. \& Suto, T. (1979). Cellular fatty acid composition of sulfatereducing bacteria. J Gen Appl Microbiol 25, 185-196.

Ueki, A., Matsuda, K. \& Ohtsuki, C. (1986). Sulfate reduction in the anaerobic digestion of animal waste. J Gen Appl Microbiol 32, 111-123.

Ueki, A., Kainuma, Y., Fujii, H. \& Ueki, K. (2000). Seasonal variations in vertical distribution of methanogenic activity and $\mathrm{Fe}$ (II) content and relationship between them in wetland rice field soil. Soil Sci Plant Nutr 46, 401-415.

Ueki, A., Akasaka, H., Suzuki, D. \& Ueki, K. (2006a). Paludibacter propionicigenes gen. nov., sp. nov., a novel strictly anaerobic, Gramnegative, propionate-producing bacterium isolated from plant residue in irrigated rice-field soil in Japan. Int J Syst Evol Microbiol 56, 39-44.

Ueki, A., Akasaka, H., Suzuki, D., Hattori, S. \& Ueki, K. (2006b). Xylanibacter oryzae gen. nov., sp. nov., a novel strictly anaerobic, Gramnegative xylanolytic bacterium isolated from rice-plant residue in flooded rice-field soil in Japan. Int J Syst Evol Microbiol 56, 2215-2221.

Wassmann, R., Neue, H. U., Lantin, R. S., Makarim, K., Chareonsilp, N., Buendia, L. V. \& Rennenberg, H. (2000). Characterization of methane emissions from rice fields in Asia. II. Differences among irrigated, rainfed, and deepwater rice. Nutr Cycl Agroecosyst 58, 13-22.

Watabe, J., Benno, Y. \& Mitsuoka, T. (1983). Taxonomic study of Bacteroides oralis and related organisms and proposal of Bacteroides veroralis sp. nov. Int J Syst Bacteriol 33, 57-64. 